\title{
A hybrid swarm of manatees along the Guianas coastline, a peculiar environment under the influence of the Amazon River plume
}

\section{CAMILLA S. LIMA ${ }^{1}$, RAFAEL F. MAGALHÃES ${ }^{2}$, MIRIAM MARMONTEL ${ }^{3}$, ANA CAROLINA MEIRELLES ${ }^{4}$, VITOR LUZ CARVALHO ${ }^{4}$, ANNE LAVERGNE ${ }^{5}$, BENOIT DE THOISY ${ }^{5,6}$ and FABRÍCIO R. SANTOS ${ }^{1}$}

\author{
${ }^{1}$ Laboratório de Biodiversidade e Evolução Molecular, Departamento de Genética, Ecologia e Evolução, ICB, \\ Universidade Federal de Minas Gerais, Av. Antonio Carlos, 6627, 31270-010 Belo Horizonte, MG, Brazil \\ ${ }^{2}$ Programa de Pós-Graduação em Zoologia, Departamento de Zoologia, ICB, Universidade Federal \\ de Minas Gerais, Av. Antônio Carlos, 6627, 31270-901 Belo Horizonte, MG, Brazil \\ ${ }^{3}$ Instituto de Desenvolvimento Sustentável Mamirauá, Estrada do Bexiga, 2584, Fonte Boa, 69553-225 Tefé, AM, Brazil \\ ${ }^{4}$ Associação de Pesquisa e Preservação de Ecossistemas Aquáticos/Aquasis, Av. \\ José Alencar, 150, Sesc Iparana, 61627-010 Caucaia, CE, Brazil \\ ${ }^{5}$ Institut Pasteur de Guyane, 23 Avenue Pasteur, BP 6010, Cayenne Cedex 97306, French Guiana, France \\ ${ }^{6}$ Kwata NGO, 16 Avenue Pasteur, BP 60672 97335, Cayenne, French Guiana, France
}

Manuscript received on March 19, 2019; accepted for publication on July 29, 2019

\begin{abstract}
How to cite: LIMA CS, MAGALHÃES RF, MARMONTEL M, MEIRELLES AC, CARVALHO VL, LAVERGNE A, DE THOISY B AND SANTOS FR. 2019. A hybrid swarm of manatees along the Guianas coastline, a peculiar environment under the influence of the Amazon River plume. An Acad Bras Cienc 91: e20190325. DOI 10.1590/00013765201920190325 .
\end{abstract}

\begin{abstract}
The West Indian (Trichechus manatus) and Amazonian (T. inunguis) manatees have a sympatric occurrence at the mouth of the Amazon River. A result of this interspecific encounter is the occurrence of hybrids, which are frequently found along the coasts of Amapá state in Brazil, French Guiana and Guyana. Here we present new genetic evidence indicating the occurrence of a hybrid swarm along the Guianas Shield coastline, which is an interspecific hybrid zone that also separates T. manatus populations located east (Brazil) and west (Caribbean, Gulf of Mexico, Florida and Antilles). In addition, we suggest that this hybrid population occupies a peculiar mangrove-rich environment under strong influence of the Amazon River plume, which requires an independent management and should be considered a special conservation area.
\end{abstract}

Key words: Conservation Genetics, Hybrid zone, Introgression, Amazon River plume, Guianas coastline, Trichechus.

\section{INTRODUCTION}

Conservation genetics provides important evidence for management of threatened species in nature and captivity (Frankel 1974, Caughley 1994). Currently, genetic data are used to understand the evolutionary dynamics of natural populations,

Correspondence to: Fabrício Rodrigues dos Santos

E-mail: fsantos@icb.ufmg.br

ORCid: https://orcid.org/0000-0001-9088-1750 which can be applied in conservation strategies to mitigate anthropogenic effects, allowing the persistence of species and their ecosystems in the medium and long term (Allendorf et al. 2010, Arif et al. 2011, Stronen and Paquet 2013). However, the conservation of interspecific hybrid populations is a matter of controversy, with the origin and context of hybridization (e.g., natural or anthropogenic) having to be considered in conservation policies (Jackiw et al. 2015). This conservation controversy 
is mostly due to association of hybrids with outbreeding depression (OD) and possible deleterious effects on both parental species (Allendorf et al. 2001), especially in cases of direct or indirect anthropogenic influence, causing human-mediated population decline of endangered species under sympatry due to intrinsic OD (e.g., Pinto et al. 2016).

In some cases, first generation hybrids are at least partially fertile and may cross with one of the parental species, resulting in introgression (Turner and Harr 2014, Balcova et al. 2016). These hybrids can compete for resources and reproductive priority, which may reduce the adaptive value of local populations of parental species and eventually lead to local or global extinction (Brumfield 2010, Wayne and Shaffer 2016). However, some natural hybrid populations may be more well adapted for survival in peculiar environments as compared to their non-hybrid parents (Allendorf et al. 2001, Fitzpatrick and Shaffer 2007), and may deserve particular protection (Jackiw et al. 2015). This is the case of hybrid zones with intermediate environments between the parental ones, where the hybrids possess ideal combinations of genes to live and thrive (Dong et al. 2003).

A case of interspecific hybridization is found in South American manatees, aquatic mammals represented by three species of the Trichechus genus (Mammalia, Sirenia, Trichechidae). In the Americas there are two species, the West Indian manatee (Trichechus manatus) that inhabits the tropical Caribbean and Atlantic coastlines, estuaries and adjacent riverine and lake systems; and the Amazonian manatee (T. inunguis) that is distributed along the Amazon River basin. Previous genetic studies have identified the occurrence of interspecific hybrids between these two manatee species close to the Amazon River mouth and along the Guianas Shield coastline, from Amapá state in Brazil to Guyana (Garcia-Rodriguez et al. 1998, Vianna et al. 2006, Santos et al. 2016). This interspecific hybrid zone also separates two largely differentiated populations (or ESUs) of T. manatus, one found along the Brazilian coast, and the other distributed from Venezuela to Florida (USA) and the Antilles (Figure 1).

\section{MATERIALS AND METHODS}

To illustrate this hybridization event, we sequenced one nuclear (Recombination activating gene 1; RAG1) and one mitochondrial DNA (control region; CR) gene fragments of $T$. inunguis (Amazonas, Brazil) and T. manatus (Rio Grande do Norte, Brazil) as parental references, plus one hybrid previously identified by Vianna et al. (2006) from Amapá (Brazil), and five samples from French Guiana: Iracoubo, Awala, Mana, Kourou and an unknown locality. We amplified the gene fragments using primers previously reported (Murphy et al. 2001). For each locus, the PCR mix was prepared with final volume of $25 \mu \mathrm{L}$, containing: $20 \mathrm{ng}$ of genomic DNA; $1 \times$ buffer; $1.5 \mathrm{mM} \mathrm{MgCl}_{2} ; 0.5$ $\mu \mathrm{M}$ each primer, $200 \mu \mathrm{M}$ dNTPs, and 0.5 units Platinum $^{\text {TM }}$ Taq DNA polymerase (Thermo Fisher Scientific). The cycles of amplification followed the conditions described by Vianna et al. (2006), with the annealing temperature of $58^{\circ} \mathrm{C}$ for RAG1. PCR products were purified by the polyethylene glycol (PEG) method (20\% PEG 8000, 2.5M $\mathrm{NaCl}$ ) (Santos-Júnior et al. 2015) and sequenced on the ABI 3130xl Genetic Analyser (Applied Biosystems) using the BigDye Termination v3.1 Cycle Sequencing kit, with the same primers used for amplification. Chromatograms were analyzed in SeqScape v2.6 and consensus sequences were aligned using the Clustal W algorithm (Larkin et al. 2007) in the software MEGA7 (Tamura et al. 2013). A total of $767 \mathrm{bp}$ and $410 \mathrm{bp}$ were sequenced for RAG1 and CR, respectively. The RAG1 haplotypes were inferred in software DNAsp 5, using the algorithm Phase (Rozas et al. 2003), and the parsimony network relationships for 


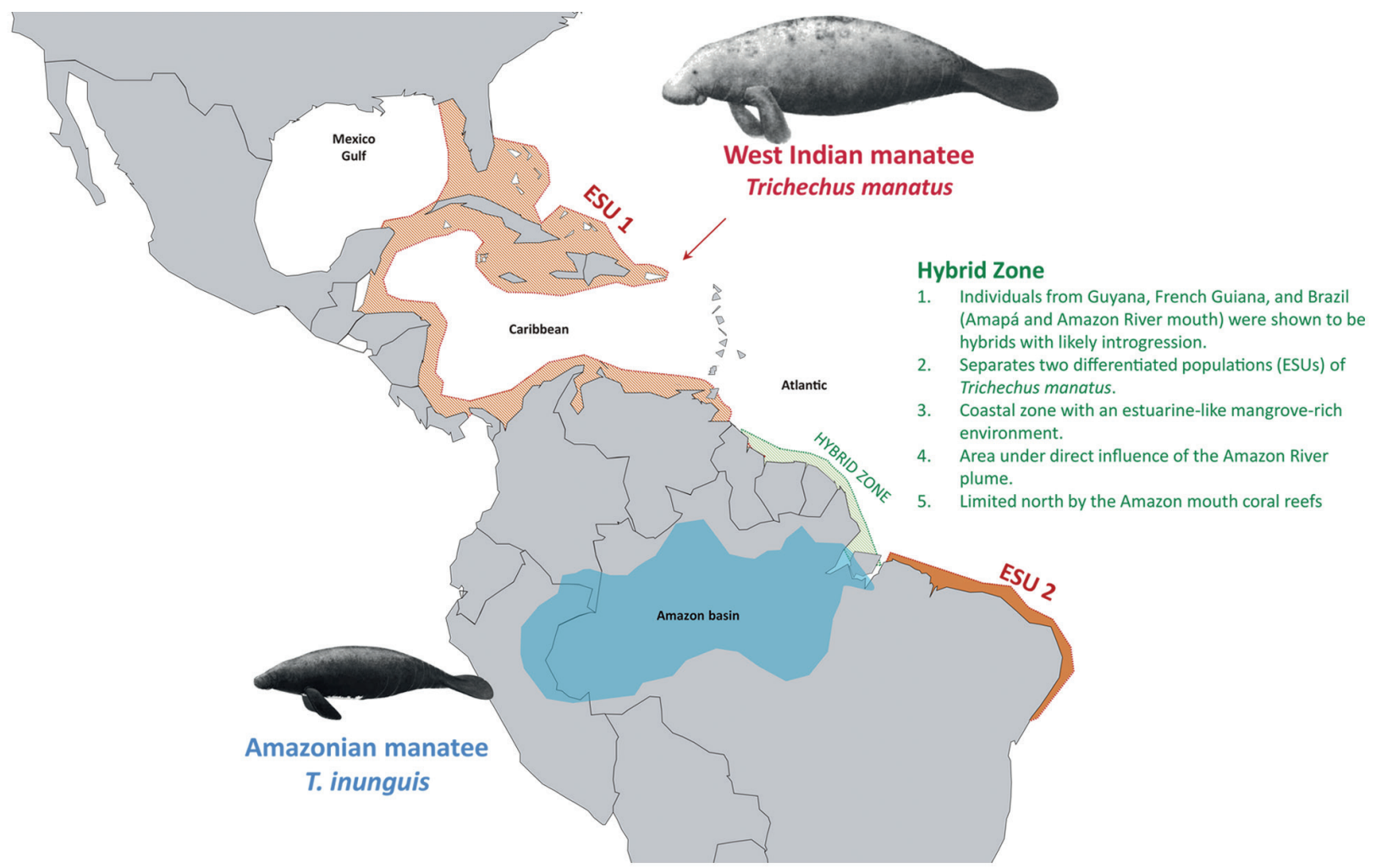

Figure 1 - Map representing the distribution of Trichechus inunguis and T. manatus populations and the interspecific hybrid zone along the Guianas Shield coastline. The western and eastern distribution of both T. manatus evolutionary significant units (ESUs) is depicted, according to genetics, cytogenetics and skull morphology evidence (Vianna et al. 2006, Santos et al. 2016, Barros et al. 2017).

CR and RAG1 haplotypes were estimated with the software POPART (Leigh and Bryant 2015) using the median-joining algorithm (Bandelt et al. 1999) (Figure 2).

We also performed a Bayesian phylogenetic analysis to show the relationship of the individuals from the hybrid zone and the parental species, using concatenated CR and RAG1 fragments. We selected the best partition scheme and nucleotide substitution models using model selection implemented in PartitionFinder v.2.1.1 (Lanfear et al. 2016), taking the codon positions of RAG1 into account. For this, we used the linked model of branch lengths and an exact search. The model selection was made using a corrected-Akaike Information Criterion. We reconstructed the Bayesian phylogeny in MrBayes v3.2 (Ronquist et al. 2012), setting the best partition scheme and its optimal models (i.e., $\mathrm{HKY}+\mathrm{I}$ for $\mathrm{CR}, \mathrm{HKY}$ for $1^{\text {st }}$ and $2^{\text {nd }}$ codon positions of RAG1, and K80+I for the $3^{\text {rd }}$ position). We made this analysis with two replicates, $1 \times 10^{6}$ generations, thinning 5000 and a burn-in of $20 \%$ of first generations. The stationarity and convergence were checked using the Tracer v1.6 (Rambaut et al. 2018).

\section{RESULTS AND DISCUSSION}

The phylogenetic networks of RAG1 and mtDNA CR (Figure 2) show the interspecific nature of individuals from the hybrid zone (green haplotypes). Five hybrids have shown $T$. inunguis CR (T, T2, R), and only one presented a T. manatus CR (J4), with a mixture of RAG1 alleles derived from both species.

The topology of the consensus tree for the concatenated RAG1 and CR fragments reveals 

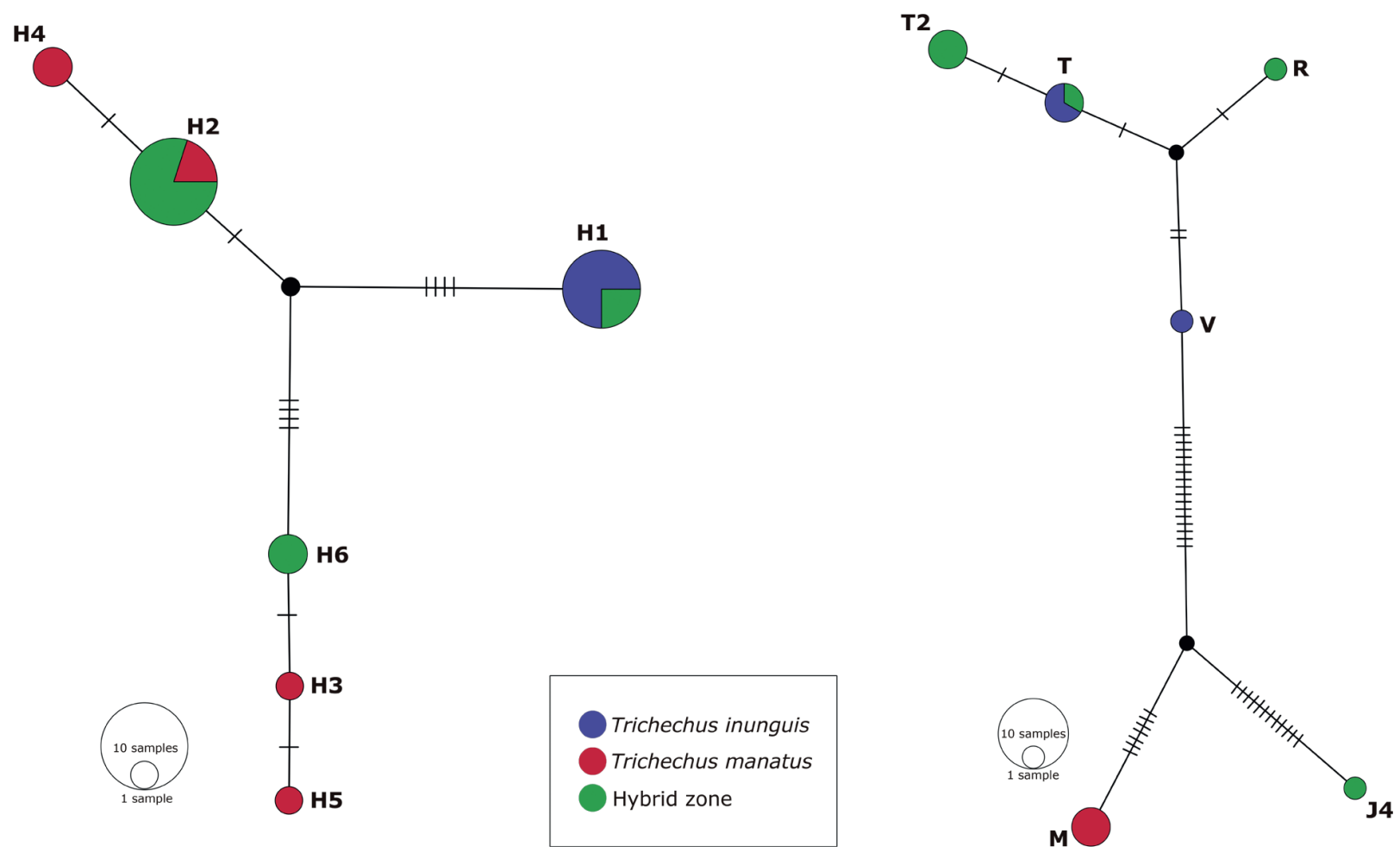

Figure 2 - Median-joining networks showing the parsimony relationships between haplotypes for RAG1 gene (left) and mtDNA control region (CR) (right). The diameter of the circles is proportional to the number of individuals with each haplotype. The transversal traces on the branches indicate the number of nucleotide substitutions. The colors refer to Trichechus inunguis (blue); Trichechus manatus (red); and manatee samples from the hybrid zone (green).

a polytomy between individuals, with a clade constituted by all T. manatus, another clade formed by $T$. inunguis and most of individuals from the hybrid zone in intermediate positions (Figure 3). A single hybrid (GFM423) is separated from other hybrids (M035, M065, M066, GFM297 and GFM524) because it is the only one with a $T$. manatus mtDNA CR. The absence of monophyly of $T$. inunguis in relation to individuals from the hybrid zone is an expected pattern observed in many studies that include introgression or backcross hybrids (Haines et al. 2014, Halas and Simons 2014, Lecaudey et al. 2018). Although our phylogeny suggests that introgressed individuals are more related to T. inunguis than to T. manatus, this is likely an artefact because the concatenation results are generally biased towards the fragment with more variation (Liu et al. 2015), in our case the mtDNA CR. For mtDNA, the close relatedness between hybrids and $T$. inunguis had already been reported for French Guiana populations (Vianna et al. 2006). However, a larger contribution of genomic DNA from $T$. manatus among the backcross hybrids was recently shown by our group (Vilaça et al. 2019).

The environment conditions of the western Atlantic Ocean have a direct influence on distribution of local marine biota, showing the Guianas coastline as a barrier between many marine species and populations (Spalding et al. 2007). The presence of hybrid manatees in this area under influence of the Amazon plume seems to be correlated both to the isolation of the western and eastern West Indian manatees (Figure 1) and the sympatric area between Amazonian and West Indian manatees (Vianna et al. 2006, Santos et al. 2016, 


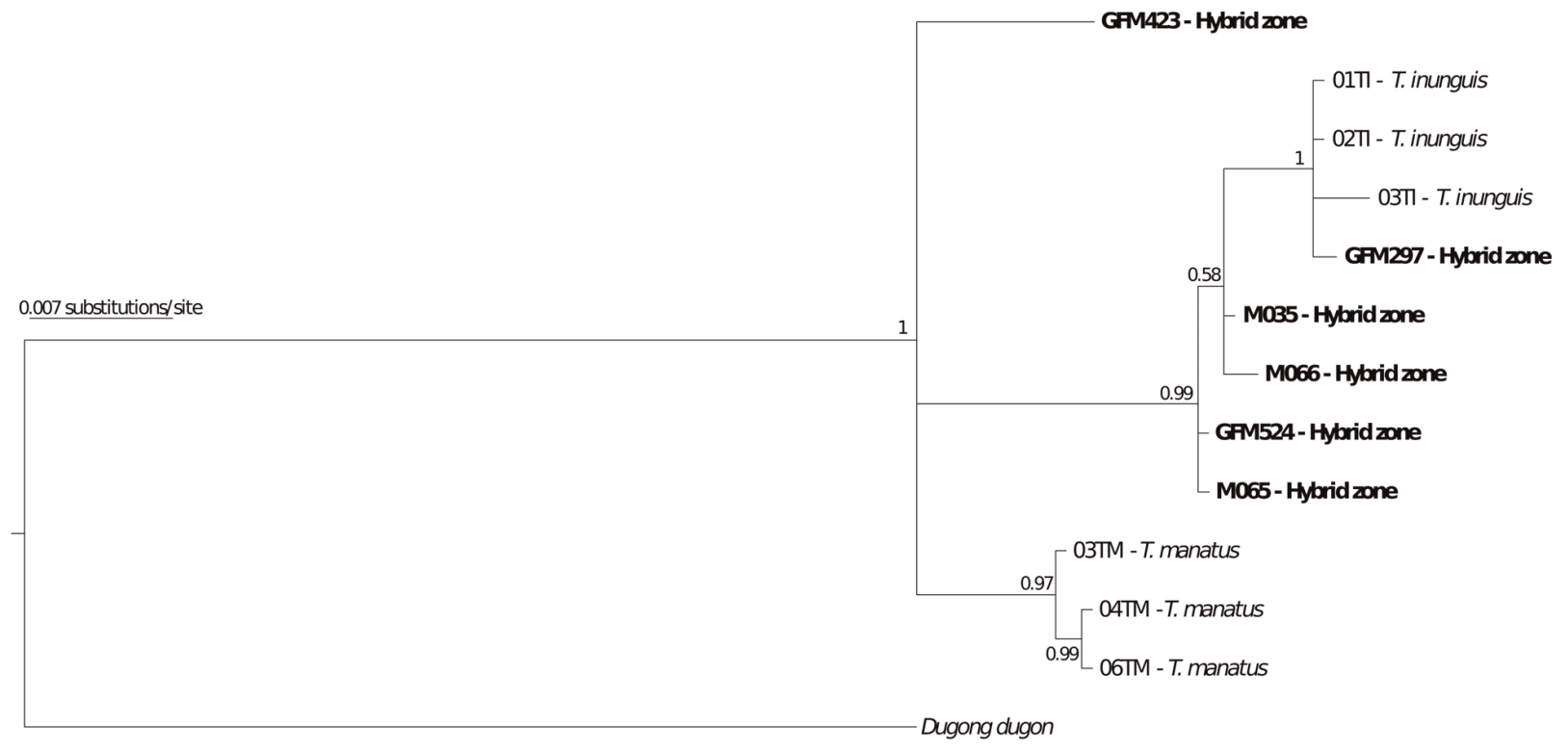

Figure 3 - Phylogenetic consensus tree of concatenated CR and RAG1 fragments of T. manatus, T. inunguis and interspecific hybrids (bold), using Dugong dugon as the outgroup. On the node labels are the posterior probabilities (PP) of each clade.

Barros et al. 2017). The coastal region between the mouths of the Amazon and Orinoco rivers (1500 $\mathrm{km}$ of coastal South America) is known by peculiar estuarine-like characteristics (Anthony et al. 2013). This unique coastal dynamics is largely influenced by the massive suspended-sediment discharge, causing a mega-turbidity on the shelf, a growth of a subaqueous delta and an intermediary salinity (Anthony et al. 2013, 2014). All these factors have a direct influence on oceanic biodiversity, including commercial marine species, coral reef endemics and threatened species completely dependent on ecosystems such as estuaries, mudflats, sandy beaches and, particularly, littoral mangroves (Artigas et al. 2003).

\section{CONCLUSIONS}

The wild population of manatees on the Guianas coastline is composed by an introgressed population derived from interspecific crossings between T. manatus and T. inunguis (Vianna et al. 2006, Santos et al. 2016), which likely happened on the sympatric area at the Amazon River mouth.
Even though the recent collapse of the populations of both parental species may be associated with some level of interspecific hybridization, the hybrid zone appears to have existed for many generations in the Guianas coastline, an intermediate coastal habitat under influence of the Amazon River plume. Indeed, because of this peculiar estuarinelike habitat between the mouths of the Orinoco and Amazon rivers, hybrids may have some advantages over the parental species, probably due to a singular combination of adapted genes to these intermediate conditions, as we have recently suggested (Vilaça et al. 2019). The large predominance of hybrids of a large aquatic mammal in an area shown to be a vicariant zone for many marine species, and a distinctive habitat for many estuary-associated animals, emphasizes the independent management of the Guianas coastline as a special protection area with a peculiar environment and biota.

\section{ACKNOWLEDGMENTS}

CSL was supported by a Coordenação de Aperfeiçoamento de Pessoal de Nível Superior 
(CAPES, Brazil) PhD fellowship, RFM by a CAPES-PNPD (Brazil) fellowship, and FRS by a Conselho Nacional de Desenvolvimento Científico e Tecnológico (CNPq, Brazil) research fellowship. This project was performed under ICMBio/SISBIO permit 45028 and received funding support from FAPEMIG, CNPq, PETROBRAS and Fundação o Boticário from Brazil.

\section{AUTHOR CONTRIBUTIONS}

Collection and sample loaning: MM, ACM, VLC, AL, BT; DNA extraction and sequencing: CSL; Phylogenetic analysis: CSL and RMF; Interpretation of data and writing of the manuscript: CSL, RMF and FRS; all authors approved the final version of the manuscript.

\section{REFERENCES}

ALLENDORF FW, HOHENLOHE PA AND LUIKART G. 2010. Genomics and the future of conservation genetics. Nat Rev Genet 11: 697-709.

ALLENDORF FW, LEARY RF, SPRUELL P AND WENBURG JK. 2001. The problems with hybrids: setting conservation guidelines. Trends Ecol Evol 16: 613-622.

ANTHONY EJ, GARDEL A AND GRATIOT N. 2014. Fluvial sediment supply, mud banks, cheniers and the morphodynamics of the coast of South America between the Amazon and Orinoco river mouths. Geol Soc London, Spec Publ 388: 533-560.

ANTHONY EJ, GARDEL A, PROISY C, FROMARD F, GENSAC E, PERON C, WALCKER R AND LESOURD S. 2013. The role of fluvial sediment supply and rivermouth hydrology in the dynamics of the muddy, Amazondominated Amapá-Guianas coast, South America: A threepoint research agenda. J South Am Earth Sci 44: 18-24.

ARIF IA, KHAN HA, BAHKALI AH, AL HOMAIDAN AA, AL FARHAN AH, AL SADOON M AND SHOBRAK M. 2011. DNA marker technology for wildlife conservation. Saudi J Biol Sci 18: 219-225.

ARTIGAS LF, VENDEVILLE P, LEOPOLD M, GUIRAL D AND TERNON J-F. 2003. Marine Biodiversity in French Guiana: Estuarine, Coastal, and Shelf Ecosystems Under the Influence of Amazonian Waters. Gayana 67: 302-326.

BALCOVA M ET AL. 2016. Hybrid Sterility Locus on Chromosome X Controls Meiotic Recombination Rate in Mouse. PLoS Genet 12: 1-16.
BANDELT HJ, FORSTER P AND RÖHL A. 1999. Medianjoining networks for inferring intraspecific phylogenies. Mol Biol Evol 16: 37-48.

BARROS HM, MEIRELLESACO,LUNAFO, MARMONTEL M, CORDEIRO-ESTRELA P, SANTOS N AND ASTUA D. 2017. Cranial and chromosomal geographic variation in manatees (Mammalia: sirenia: Trichechidae) with the description of the Antillean manatee karyotype in Brazil. J Zool Syst Evol Res 55: 73-87.

BRUMFIELD RT. 2010. Speciation genetics of biological invasions with hybridization. Mol Ecol 19: 5079-5083.

CAUGHLEY G. 1994. Directions in conservation biology. J Anim Ecol 63: 215-244.

DONG Z, XUE-DONG L AND JIAN-ZHANG M. 2003. Hybrid zone and its genetic analysis: implication for conservation. J For Res 14: 167-170.

FITZPATRICK BM AND SHAFFER HB. 2007. Hybrid vigor between native and introduced salamanders raises new challenges for conservation. Proc Natl Acad Sci 104: 15793-15798.

FRANKEL OH. 1974. Genetic conservation: our evolutionary responsibility. Genetics 78: 53-65.

GARCIA-RODRIGUEZ AI, BOWEN BW, DOMNING DP, MIGNUCCI-GIANNONI AA, MARMONTEL M, MONTOYA-OSPINA RA, MORALES-VELA B, RUDIN M, BONDE RK AND MCGUIRE PM. 1998. Phylogeography of the West Indian manatee (Trichechus manatus): how many populations and how many taxa? Mol Ecol 7: 1137-1149.

HAINES ML, MOUSSALLIA, STUART-FOX D, CLEMANN N AND MELVILLE J. 2014. Phylogenetic evidence of historic mitochondrial introgression and cryptic diversity in the genus Pseudemoia (Squamata: Scincidae). Mol Phylogenet Evol 81: 86-95.

HALAS D AND SIMONS AM. 2014. Cryptic speciation reversal in the Etheostoma zonale (Teleostei: Percidae) species group, with an examination of the effect of recombination and introgression on species tree inference. Mol Phylogenet Evol 70: 13-28.

JACKIW RN, MANDIL G AND HAGER HA. 2015. A framework to guide the conservation of species hybrids based on ethical and ecological considerations. Conserv Biol 29: 1040-1051.

LANFEAR R, FRANDSEN PB, WRIGHT AM, SENFELD T AND CALCOTT B. 2016. PartitionFinder 2: New Methods for Selecting Partitioned Models of Evolution for Molecular and Morphological Phylogenetic Analyses. Mol Biol Evol 34: 772-773.

LARKIN M ET AL. 2007. ClustalW and ClustalX version 2. Bioinformatics 23: 2947-2948.

LECAUDEY LA, SCHLIEWEN UK, OSINOV AG, TAYLOR EB, BERNATCHEZ L AND WEISS SJ. 2018. Inferring phylogenetic structure, hybridization and divergence times 
within Salmoninae (Teleostei: Salmonidae) using RADsequencing. Mol Phylogenet Evol 124: 82-99.

LEIGH JW AND BRYANT D. 2015. In: Nakagawa S (Ed), PopArt: full-feature software for haplotype network construction. Methods Ecol Evol 6: 1110-1116.

LIU L, XI Z, WU S, DAVIS CC AND EDWARDS SV. 2015. Estimating phylogenetic trees from genome-scale data. Ann NY Acad Sci 1360: 36-53.

MURPHY WJ, EIZIRIK E, JOHNSON WE, ZHANG YP, RYDER OA AND O'BRIEN SJ. 2001. Molecular phylogenetics and the origins of placental mammals. Nature 409: 614-618.

PINTO PV, BEJA P, FERRAND N AND GODINHO R. 2016. Hybridization following population collapse in a critically endangered antelope. Sci Rep 6: 1-9.

RAMBAUT A, DRUMMOND AJ, XIE D, BAELE G AND SUCHARD MA. 2018. Posterior Summarization in Bayesian Phylogenetics Using Tracer 1.7. Syst Biol 1-5.

RONQUIST F, TESLENKO M, VAN DER MARK P, AYRES DL, DARLING A, OHNA S, LARGET B, LIU L, SUCHARD MA AND HUELSENBECK JP. 2012. Software for Systematics and Evolution MrBayes 3.2: Efficient Bayesian Phylogenetic Inference and Model Choice Across a Large Model Space. Syst Biol 61: 539542.

ROZAS J, SÁNCHEZ-DELBARRIO JC, MESSEGUER X AND ROZAS R. 2003. DnaSP, DNA polymorphism analyses by the coalescent and other methods. Bioinformatics 19: 2496-2497.

SANTOS FR, BARROS HM, SCHETINO MAA AND LIMA CS DE. 2016. Genetics. In: Meirelles AC and Carvalho VL (Eds), West Indian Manatee Biology and Conservation in Brazil/ Peixe-boi Marinho Biologia e Conservação no Brasil, São Paulo: Bambu editora e artes gráficas, p. 63-75. SANTOS-JÚNIOR JE, SANTOS FR AND SILVEIRA FA. 2015. Hitting an Unintended Target: Phylogeography of Bombus brasiliensis Lepeletier, 1836 and the First New Brazilian Bumblebee Species in a Century (Hymenoptera: Apidae). PLoS ONE 10: e0125847.

SPALDING MD ET AL. 2007. Marine Ecoregions of the World: A Bioregionalization of Coastal and Shelf Areas. Bioscience 57: 573-583.

STRONEN AV AND PAQUET PC. 2013. Perspectives on the conservation of wild hybrids. Biol Cons 167: 390-395.

TAMURA K, STECHER G, PETERSON D, FILIPSKI A AND KUMAR S. 2013. MEGA6: Molecular evolutionary genetics analysis version 6.0. Mol Biol Evol 30: 2725 2729.

TURNER LM AND HARR B. 2014. Genome-wide mapping in a house mouse hybrid zone reveals hybrid sterility loci and Dobzhansky-Muller interactions. Elife 3: 1-25.

VIANNA JA ET AL. 2006. Phylogeography, phylogeny and hybridization in trichechid sirenians: implications for manatee conservation. Mol Ecol 15: 433-447.

VILAÇA ST, LIMA CS, MAZZONI CJ, SANTOS FR AND DE THOISY B. 2019. Manatee genomics supports a special conservation area along the Guianas coastline under the influence of the Amazon River plume. Estuar Coastal Shelf Sci 260: 106286.

WAYNE RK AND SHAFFER HB. 2016. Hybridization and endangered species protection in the molecular era. Mol Ecol 25: 2680-2689. 